Article

\title{
OFDI Agglomeration and Chinese Firm Location Decisions under the "Belt and Road" Initiative
}

\author{
Haiyue Liu, Jie Jiang, Lei Zhang * and Xiaolan Chen *D \\ School of Business, Sichuan University, Chengdu 610065, China; seamoon@scu.edu.cn (H.L.); \\ 18523136743@163.com (J.J.) \\ * Correspondence: zhanglei@scu.edu.cn (L.Z.); chenxiaolan@scu.edu.cn (X.C.)
}

Received: 25 September 2018; Accepted: 1 November 2018; Published: 6 November 2018

\begin{abstract}
This paper established a combined dataset from 2004 to 2015 for 129 host countries and matched them with 1193 Outward Foreign Direct Investment (OFDI) events by Chinese listed firms. Four variables were designed to proxy the agglomeration effects of Chinese OFDI at both an industry and country level. Probit and FGLS estimation methods were used to analyze whether the Chinese listed firm location choices were affected by the agglomeration level. It was found that the agglomeration effect of Chinese OFDI on host country selection was obvious, as Chinese firms were often found to follow other Chinese firms and invest in host countries where Chinese investment was concentrated; however, it was also found that Chinese firms did not choose countries where there was a high concentration of non-Chinese FDI. The agglomeration effect on Chinese OFDI industry selection was also significant. Firms were found to invest in industries that already had large Chines OFDI agglomeration or high host-country industrial agglomeration. Further investigations found that the "Belt and Road" Initiative (BRI) was effective in guiding location decisions. Firms were found to invest more along the "Belt and Road" route after the BRI was launched; however, large State-owned listed firms with higher leverage but lower productivity and profitability were found to more often invest along the BRI routes.
\end{abstract}

Keywords: agglomeration; belt and road; location choice; OFDI

\section{Introduction}

The "Belt and Road" Initiative (BRI) was launched in 2013 as a consensus-based multinational cooperative framework that relies on existing Chinese dual multilateral mechanisms and existing regional cooperative platforms in particular countries. Borrowing from the ancient Silk Road, the BRI aims to actively develop economic cooperation with the countries along the nominated sea and land routes through the development of political mutual trust, economic integration, and cultural inclusion. In line with these BRI developments, Chinese firms have been progressively investing in countries along the route. OBOR (One Belt One Road) has become an important destination for China's foreign direct investment. According to MOFCOM (Ministry of Commerce of People's Republic of China) Statistics, in 2016 among the 196.2 billion US dollars of Chinese OFDI, there are 14.5 billion US dollars flowing into OBOR region which accounted for $8.5 \%$ of the total and increased by $72.49 \%$ compared with China's OFDI stocks along OBOR by 2006. The proportion of Chinese OFDI along OBOR also increased from $6.81 \%$ in 2006 to $9.53 \%$ in 2016 . Moreover, there is an obvious phenomenon of investment aggregation along the route. Within the OBOR region, 10 ASEAN countries attract the most investment from China and accounted for $55.29 \%$ of the total stock. Looking on the country-level, Singapore attracted nearly a quarter of Chinese OFDI along OBOR. Russia, Indonesia, Kazakhstan, etc. are also main destinations of Chinese OFDI (see Appendix A Tables A1-A3 for details). Looking on the firm-level, 56 cooperation zones have been established, and 107 state-owned enterprises (SOEs) had 
invested in BRI construction projects such as roads, ports, energy, engineering contracting, industrial parks, and other infrastructure facilities. Listed firms are actively participating in OBOR projects encouraged by all levels of governments.

Although BRI provided a package of stimulus such as financing facilities, registration conveniences, etc. which boost investments, OBOR countries' political, economic, cultural, legal environmental differences, and instabilities are still obstacles for Chinese firms' OFDI. Due to the uncertainties in the host countries' market, and the inability to reverse the investment, Chinese firms often adopt a follow-up mode when making OFDI location decisions. Research has found that when Chinese firms are making location choices, their investment motives and investment layouts are often influenced by peers or trends, resulting in different levels of investment agglomeration [1].

In recent years there has also been significant research into Chinese firm' s OFDI locations and industry concentration, with many studies noting that Chinese OFDI firms tend to cluster in high-risk host countries [2-4] and a stable and continuous agglomeration effect in Chinese OFDI has been discovered [1,5]. Although previous research has reached a certain degree of consensus on the foreign investment decision-making behavior of Chinese firms, these studies has been mostly limited to country-level data. However, for comprehensive BRI analysis, there needs to be a more detailed examination of firm-level location policies to provide concrete evidence for the institutional factors associated with the agglomeration effect. To do this, a Probit model is employed to estimate the effects of Chinese OFDI agglomeration and non-Chinese FDI agglomeration in host economies on investment location choices from 2004 to 2015 . Using a large dataset constructed from detailed individual firm OFDI events information, it was possible to measure the effects of the country of origin and the industry on a firm's location choice. It is also examined whether firms tend to invest more in OBOR countries after the BRI. Finally, firm investments are linked with firm characteristics such as size, profitability, and productivity. Somewhat different from Head et al. [6], this study found that Chinese investors preferred to locate near other Chinese firms in a host country rather than near non-Chinese firms. As the Probit estimation results revealed that more Chinese firms tended to locate in OBOR countries after 2013, an FGLS model was used to determine the types of firms that had clustered in OBOR countries when making OFDI location choices.

This research contributes to existing literature on agglomeration economies, international firm location choices, foreign direct investment, and institutional interventions from home countries. To the best of our knowledge, this is the first study of agglomeration effects on Chinese investment location choices under the BRI. The empirical results are particularly important for Chinese firms as well as authorities when seeking to design policies aimed at promoting OFDI.

The remainder of this paper is organized as follows. Following the literature review on localization and the presentation of the hypotheses in Section 2, in Section 3, the dataset and variables are described, and in Section 4, the methodology and empirical results are presented. Section 5 gives the final conclusions from the analyses.

\section{Literature Review}

Industry localization is defined as "the geographic concentration of particular industries" [6]. One of the mechanisms motivating this type of concentration is the existence of agglomeration economies, which are positive externalities that stem from the geographic clustering of certain industries. In this context, the investing firms contribute to and benefit from the externalities [7]. The theory of agglomeration economies was first introduced by Marshall [8], who outlined three reasons for the clustering of similar firms from the same industries; a pooled market for workers with specialized skills, easier development of specialized inputs and services, and benefits from technological spillovers. Krugman [9] and Saxenian [10] later constructed formal models to analyze and extend the agglomeration economies concepts. Research has found that multinational corporations tend to take a networked production coordination approach with associated companies in specific agglomeration areas to achieve optimal economies of scale, which often means that foreign investment 
location choices are highly aggregated. Consequently, the agglomeration effect has become a factor when determining a firm's OFDI behavior, not only in their investment location choice, but also in the industries in which the firms belong; that is, firms from the same industry sector tend to follow each other's investment choices [11-16].

Firms are able to enhance their performance by the positive externalities generated through agglomeration. Marshall [8] identified three externalities that stemmed from industry localization: technological spillovers, a pooled market of workers with specialized skills, and a pool of specialized intermediate inputs for the industry. Generally, it has been found that firms can benefit from geographical localization in agglomeration economies. To date, there have been two types of studies on agglomeration benefits. The first have been qualitative studies that identify industry clusters and documented agglomeration externality mechanisms $[9,10]$, and the second have been empirical studies that sought to determine the accruing benefits when a firm located near to other firms in the same industry or from the same country of origin. For example, the empirical research of Head et al. [6], Head and Ries [17], Head, Ries and Swenson [18], Crozet et al. [19], Guimaraes et al. [13], and Coughlin and Segev [20] all found that firms in the same industries and from the same countries of origin tended to locate near to each other. However, Shaver and Flyer [7] found that in many agglomeration economies, many firms performed better if they did not cluster as firms are able to gain benefits from agglomeration economies as well as contribute. Therefore, large firms with better technologies, human capital, training programs, suppliers, and distributors often attempt to locate away from their competitors because the benefits they gain from locating near their competitors are less than the benefits the competitors gain from them.

In this study, based on the OFDI patterns in China, six hypotheses aimed at verifying the existence of agglomeration economies are tested.

Head et al. [18] argued that the agglomeration effects between Japanese firms may have appeared because of their different characteristics from the firms of other countries. For example, the preference for higher skilled workers because of a stronger desire for quality control or the greater use of complex machinery could motivate a new Japanese firm to locate near earlier arrivals so as to hire employees who had already been trained in Japanese methods. Chinese OFDI research into investment locations and industry concentrations has suggested that Chinese OFDI firms have tended to focus on high-risk host countries [2-4]. So, firm's OFDI location decision tends to follow their Chinese peers for safety reasons. Qi and Liu [21] studied the influence of past experience on Chinese OFDI location choices and found that OFDI firms conducted sequential market selection based on the investment experience of other firms, which they described as a "herd effect". Therefore, it is possible to expect that there is an empirical relationship between the location choice or industry choice by new Chinese firms and prior Chinese firm investments in a particular host country. Based on the location patterns of Chinese multinationals, it is proposed that Chinese investors tend to concentrate in a particular region or industry. Based on existing findings, therefore, we developed the following Hypothesis 1 :

Hypothesis 1. New Chinese investors tend to invest in host countries that already have large Chinese origin FDI stock.

Empirical research on different countries-Boudier-Bensabaa [22] on Hungary, Meyer and Nguyen [23] on Vietnam, Head and Ries [18] and Cheng and Ruan [24] on China, Crozet et al. [19] on France, and Guimaraes et al. [13] on Portugal-all found that new foreign firms were likely to locate near to other foreign investors so as to use the experience and performance of the earlier investors as indicators of the underlying business climate at the specific location. Therefore, it is possible that there is an empirical relationship between the location choice of a new foreign firm and prior investment by other foreign firms in a particular destination. The lagged volume of FDI to the same host countries is used as a proxy for country-specific agglomeration; therefore, we developed the following Hypothesis 2: 
Hypothesis 2. New Chinese investors tend to invest in a host country that has already attracted a large volume of foreign FDI.

Head, Ries, and Swenson [18], Crozet et al. [19], Guimaraes et al. [13], and Coughlin and Segev [20] also found that firms in the same industry tended to invest near to each other and that the types of industry played an important role when choosing which home country firms to invest in. Because of obvious information asymmetry, firms pay more attention to the behavior of firms in similar industries when making their investment decisions [25]. As international mutual investment inevitably affects the competitive environment in the investing countries and the international market, firms pay attention to their counterparts' investment decisions, and therefore, to reduce competition and avoid uncertainties from the industry side, firms tend to follow the investment decisions of pioneer firms [26]. Lin [27] had suggested that there was a "surge phenomenon", whereby firms from a developing country are likely to reach a consensus when selecting new and promising industries due to information asymmetry, which then resulted in clustered investment in the identified industry. Therefore, compared to other industries in the home country, firms from the same industry in the same country affect the investment decision-making of later firms. Hence, we propose Hypothesis 3:

Hypothesis 3. New Chinese investors tend to invest in an industry that has already attracted large Chinese OFDI.

Multinational investors and especially investors from developing countries have a strong demand for local knowledge in the host country [28,29]. Usually, if a firm wants to acquire local knowledge, it can choose to invest in the industrial agglomeration areas of the host country, interact with the local firms, and conduct horizontal and vertical learning [30,31]. Therefore, the industrial agglomeration areas in the host country have a strong attraction to international firms, especially in the manufacturing sector. The higher the level of local industrial agglomeration, the more the knowledge spillover. Regions with relatively high industrial agglomeration levels, therefore, attract upstream and downstream firm agglomeration and related services [32], all of which enables firms to improve their production efficiencies $[9,33]$. Therefore, Hypothesis 4 was developed to assess Chinese firms' response to host-country industrial agglomeration when conducting OFDI.

Hypothesis 4. Larger shares of certain industries in host countries attract a greater number of new Chinese investors in the same industry.

The BRI aims to connect China more closely to Central Asia, Southeast Asia, South Asia, Russia, and the Baltics. The BRI has proven effective as the Chinese government strongly promotes investment in OBOR countries. Before 2013, OBOR related countries had not been the main destinations for Chinese OFDI, only accounting for $10.8 \%$ of total Chinese OFDI. After 2013, however, the OBOR related countries became a preferred destination for construction project investment. In 2015, Chinese OFDI investment projects tended to be infrastructure facilities such as railways, airports, power grids, water conservancies, and port engineering, at over $70 \%$ of all Chinese OFDI. New foreign construction project contracts signed between China and OBOR related countries reached a record high of 92.6 billion USD and accounted for $44 \%$ of the total newly signed foreign construction projects (MinSheng Securities Research Institute, "Belt and Road" Report 2015.). Researches show the labor force, natural resources endowment, and bilateral investment agreements in OBOR areas have a significant role in promoting investment [34]. Some scholars empirically analyze the industrial comparative advantages and complementarity between China and the countries (regions) along the route, and point out that the optimal choice of the countries and industries along the route can speed up the international industrial chain layout of domestic industries, accelerate the transfer of excess capacity and boost manufacturing upgrade [35,36]. Bilateral investment agreements (BIT) signed between China and OBOR countries play a particularly significant role in promoting and protecting 
Chinese firms' foreign direct investment and encouraging investment activities in these areas [35]. As this paper is assessing the links between the BRI and Chinese OFDI agglomeration and the effect of BRI on firm location choices, Hypothesis 5 was developed:

Hypothesis 5. The BRI encourages new Chinese investors to locate in countries along the OBOR route.

This paper further analyzes the characteristics of firms investing in OBOR countries. Firms that are actively investing in OBOR countries are generally those that are facing fierce domestic competition and eagerly seeking outlets for their excess productivity [4]. One motivation behind the BRI was the urgent need for industrial structural upgrading especially for industries that had surplus capacity in China such as infrastructure construction. When Chinese domestic markets reached saturation, many firms began to experience profitability and productivity decreases. Based on existing literature, the relationship between FDI and firm labor productivity is found to be highly connected. Generally, OFDI promotes parent firm's labor productivity and total factor productivity through reverse technology spillover effect. In addition, scholars also explained that firms with higher productivity will take more FDI actions [37-39].

Relating to Chinese OFDI, one strand of researches agrees that OFDI firms have productivity advantages, and the higher the productivity of the firm, the greater the possibility of OFDI $[40,41]$. Another strand of researches argues firms with bigger total asset and revenue but lower productivity tend to invest more in host countries and Chinese OFDI has poor performance financially [42-44], and firms with low efficiency can hardly generate a synergy effect when they conduct direct investment internationally $[40,41]$, especially in a very uncertain overseas investment environment. Tang Xiaojun and Zhang Jinming [41] found that compared with the heterogeneous factor of productivity, the nature of firm ownership plays a more important role in Chinese manufacturing firms' FDI, and state-owned firms have more advantages in OFDI but lower productivity compared to private firms. Consequently, under the "OBOR" initiative, the government emphasizes that large state-owned enterprises should become the main body and support of the construction, and play a more active role in participating in international competition and international capacity cooperation $[35,45,46]$. Large state-owned firm began playing a dominant OFDI role in the BRI countries; with this in mind, we developed Hypothesis 6:

Hypothesis 6. Chinese firms investing more in OBOR countries are larger but have lower productivity and profitability.

\section{Data Selection and Description of Variables}

\subsection{Data}

A combined dataset from 2004 to 2015 was established with 129 host countries: 64 OBOR countries and 66 non-OBOR countries (the countries that belong to OBOR countries were chosen based on the criteria disclosed by the Chinese Ministry of Commerce) (see Appendix C Tables A5 and A6 for details). The host-country Chinese OFDI dataset was compiled from the Chinese OFDI Report by the Ministry of Commerce that included OFDI volume (both flow and stock) at the country level. Other host-country specifics were extracted from IFS, the World Bank, and the OECD to match the OFDI locations, after which 1193 Chinese listed firm OFDI events from 2004 to 2015 were extracted into the host-country dataset. The names, investment volumes, years, host-countries, and other investment-related information were extracted from the Directory of Chinese Foreign Investment Enterprises collected by the Ministry of Commerce. The firm-level data-financial ratios, firm characteristics, and structure-were then matched and merged from their respective annual reports in the CSMAR database. 
Based on associated accounting standards, direct investment can be divided into subsidiaries, joint ventures, and associates depending on how many shares of the invested target firm are held. Therefore, in accordance with these definitions, this paper used the CSMAR related transaction database to screen for the transaction events that matched these three investment types, and the Foreign Direct Investment Enterprise Directory issued by Ministry of Commerce was also consulted to further match the events with detailed investment information. The selection criteria were (i) the registered place of the target firm was overseas; (ii) the OFDI event was complete; (iii) it was not a financial firm; and (iiii) the OFDI events with the target firms were not located in the Cayman, Islands, Bermuda, Hong Kong, or other typical tax havens. A sample of 1193 OFDI events from Chinese listed firms that had conducted OFDI in 58 host countries from 2004 to 2015 were finally extracted. As can be seen in Figure 1, of the 129 countries from 2004 to 2015, 1193 OFDI events took place as specific country-year observations (499 observations in OBOR countries) and 1327 country-year observations did not receive any OFDI from Chinese listed firms. In the samples that received Chinese OFDI, Figure 2 shows that the manufacturing industry investment was dominant in both OBOR and non-OBOR countries.

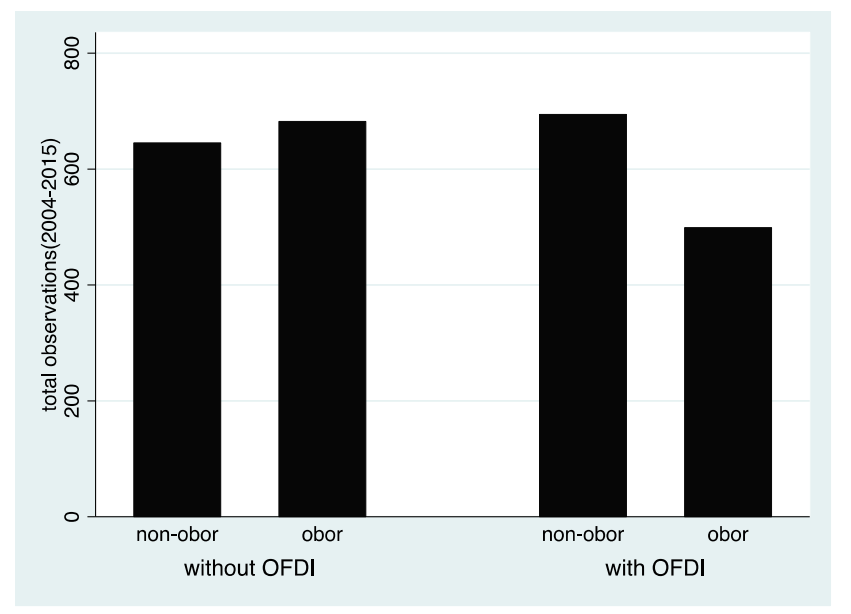

Figure 1. Distribution of observations in data (country level, 2004-2015).

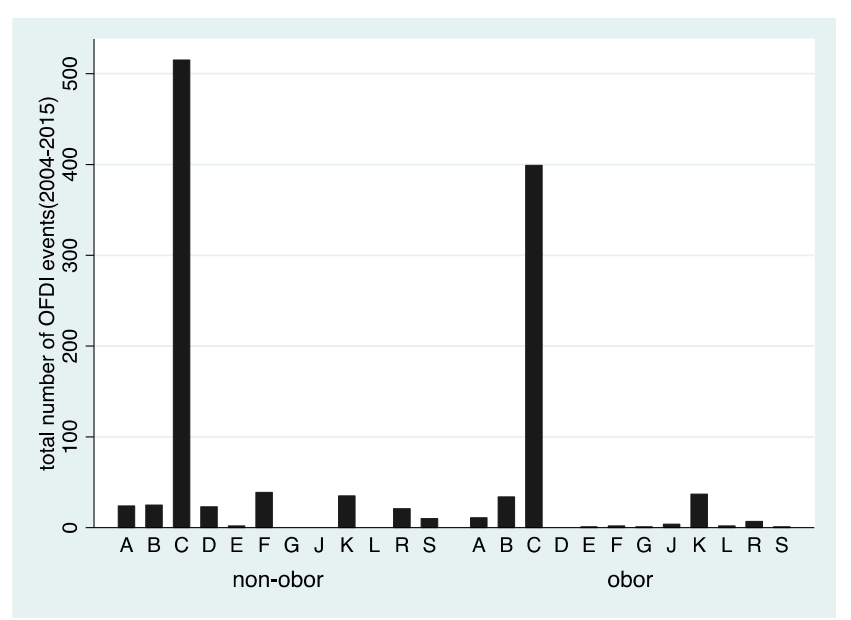

Figure 2. Distribution of Outward Foreign Direct Investment (OFDI) events in data (industry (Industry classification criteria is taken from the Industry Standard of CSRC (China Securities Regulatory Commission). A = Agriculture, Forestry, Animal Husbandry and Fishery; B = Mining; $\mathrm{C}=$ Manufacturing; $\mathrm{D}=$ Electrical Power, Heating, Natural Gas and Water; $\mathrm{E}=$ Construction; $\mathrm{F}=$ Wholesale and Retail; $\mathrm{G}=$ Transportation, Logistics and Postal Services; $\mathrm{H}=$ Food and Lodging; $\mathrm{I}=$ Information Transmission, Software, Information Services; $\mathrm{K}=$ Real Estates; $\mathrm{L}=$ Rental and Commercial Services; N = Water Conservancy, Environmental and Public Infrastructure; S = Others.) level, 2004-2015). 


\subsection{Variables}

\subsubsection{Dummy Variables for the Probit Estimation}

To construct the Probit estimation, ofdi and obor were designed as two dummy variables. In our sample, ofdi $=1$ was marked when a firm has OFDI in that certain host country, otherwise it was marked $o f d i=0$. Also obor $=1$ was marked if a firm's investment took place in OBOR countries, otherwise obor $=0$.

\subsubsection{Agglomeration Effect Variables}

This paper examined the agglomeration effect at both a country and industry level to determine if Chinese firms were investing more in countries with a larger percentage of Chinese OFDI flow or in industries with a larger share of that industry-related OFDI flow in a certain year. Unlike previous research that attempted to identify the agglomeration effects from increased OFDI in the host country $[47,48]$ or took the OFDI experience of other firms as the dummy variable to identify a herd effect [21], in this paper, it was postulated that the agglomeration effect occurred when the firms followed previous Chinese and foreign firm OFDI investment decisions in previous years. Four indices were developed to quantify the host-country and industry agglomeration effect.

(1) Lrfdi_byChina $a_{t-1, j}$ was the log OFDI volume of Chinese firms in country $j$ in year $t-1$. This variable was used to test Hypothesis 1.

(2) Lrfdi_by foreign $n_{t-1, j}$ was the log OFDI volume of other foreign firms in country $j$ in year $t-1$. This variable was used to test Hypothesis 2.

(3) Agg_byindustry $y_{t, j, k}$ was the ratio between Chinese firm OFDI volumes in industry $k$ in country $j$ at year $t-1$ over the total OFDI volume of Chinese firms in year $t-1$ in country $j$ and total OFDI volume in industry $k$ from all countries in year $t-1$ over the total OFDI volume in all industries at year $t-1$. This variable was used to test Hypothesis 3.

$$
\text { Agg_byindustryt-1,j,k}=\left(V_{t-1, j, k} / \sum_{k=1}^{n} V_{t-1, j, k}\right) /\left(\sum_{j=1}^{n} V_{t-1, j, k} / \sum_{j=1}^{n} \sum_{k=1}^{n} V_{t-1, j, k}\right)
$$

(4) Industryshare_host $t_{t-1, j, k}$ was the share of a certain industry in host countries, and was used to depict the agglomeration degree of that industry in the host country. This variable was used to test Hypothesis 4 .

\subsubsection{Other Variables}

The definitions for the other variables and data sources on a country and firm level are listed in Table 1 below. Descriptive statistics are shown in Table 2. 
Table 1. Other variables used in the estimation.

\begin{tabular}{|c|c|c|}
\hline Variables & Definitions & Original Source of Data \\
\hline \multicolumn{3}{|l|}{ Country-Level } \\
\hline lcap & Logged firm's OFDI investment volume. & $\begin{array}{l}\text { CSMAR, Statistical Bulletin of China's Outward } \\
\text { Foreign Direct Investment }\end{array}$ \\
\hline gdp_growth & GDP growth rate was used to test the market potential of the host countries. & World Bank \\
\hline infra ${ }^{1}$ & $\begin{array}{l}\text { This measured the nation's overall infrastructure construction level and was taken as a proxy for the } \\
\text { natural logarithm of fixed telephone subscriptions per } 100 \text { people [49]. }\end{array}$ & IMF \\
\hline resource & $\begin{array}{l}\text { The total natural resource rents (\% of GDP). The total natural resource rents were defined as the sum of oil } \\
\text { rents, natural gas rents, coal rents (hard and soft), mineral rents, and forest rents. }\end{array}$ & World Bank \\
\hline lmeanr & $\begin{array}{l}\text { Logged term for the average monthly real exchange rates around year } t \text { (defined to include all monthly } \\
\text { observations during year } t-1 \text { and year } t \text { ) for each host country. It measured the exchange rate level of } \\
\text { the host country's currency. An increase meant a host-country currency depreciation and vice versa }[4,50] \text {. }\end{array}$ & $\begin{array}{l}\text { Authors' calculation } \\
\text { (Monthly real exchange rate data from IFS Database) }\end{array}$ \\
\hline Lrw & Logged term of host country's real GDP per capital was used to proxy the labor cost. & World Bank \\
\hline$P E$ & $\begin{array}{l}\text { The time-varying, country-specific International Country Risk Guide (ICRG) index provided by the } \\
\text { Political Risk Services (PRS) Group was used to proxy PE. It was composed of } 12 \text { weighted variables } \\
\text { covering both political and social attributes (see Appendix B Table A4). The index indicated that an } \\
\text { increasing value represented lower political risk. }\end{array}$ & PRS Group \\
\hline ltech & $\begin{array}{l}\text { Logged term of percentage of high-tech export was used to measure the host country's level of } \\
\text { technological development. }\end{array}$ & The United Nations \\
\hline \multicolumn{3}{|l|}{ Firm-Level } \\
\hline ltotalasset & $\begin{array}{l}\text { This was the logged value of the total assets of the firm. It measured firm size in the year of the } \\
\text { investment event. }\end{array}$ & CSMAR \\
\hline leverage & $\begin{array}{l}\text { This measured the firm's degree of financial leverage (DFL) or financial risk exposure. } \\
\mathrm{DFL}=(\triangle \mathrm{EPS} / \mathrm{EPS}) /(\triangle \mathrm{EBIT} / \mathrm{EBIT})\end{array}$ & CSMAR \\
\hline eps & Earnings per share; a higher eps implied better profitability. & CSMAR \\
\hline roa & Measured the firm's Rate of Return on assets; a higher roa implied a higher return on investment. & CSMAR \\
\hline$t f p \_l p$ & $\begin{array}{l}\text { Total-factor productivity, which was calculated using the LP method. The natural logarithm form of the } \\
\text { firms' net profit (L_netprofit), the natural logarithm form of the firms' number of employees (llabor), and } \\
\text { the natural logarithm form of the firms' total assets (lotalasset) were used for the computation; a higher } \\
\text { tfp_lp implied higher efficiency. }\end{array}$ & Author's calculation \\
\hline lproductivity_add ${ }^{2}$ & $\begin{array}{l}\text { A firm's total labor productivity, which was calculated using the ratio of the total value:added revenue } \\
\text { (total revenue:total cost) over total employees. }\end{array}$ & Author's calculation \\
\hline
\end{tabular}


Table 2. Descriptive statistics.

\begin{tabular}{cccccc}
\hline Variable & Obs & Mean & Std. Dev. & Min & Max \\
\hline Lfdi_foreign & 2206 & 14.79 & 8.367 & -16.12 & 22.76 \\
Lrfdi_bychina & 2043 & 1.935 & 5.577 & -16.12 & 11.20 \\
Agg_byindustry & 2133 & 24.58 & 240.4 & 0 & 4917 \\
Industryshare_host & 2065 & 58.70 & 16.24 & 14.83 & 93.76 \\
lrw & 2248 & 4.085 & 1.585 & 0.420 & 7.055 \\
lmeanr & 2145 & -3.148 & 2.959 & -7.488 & 15.44 \\
ltotalasset & 1191 & 23.16 & 1.211 & 20.03 & 25.76 \\
ltech & 2092 & 17.98 & 7.254 & -25.33 & 26.12 \\
pe & 2103 & 3.622 & 1.171 & 1.333 & 5.920 \\
resource & 2273 & 15.44 & 19.38 & 0.000372 & 92.02 \\
infra & 2489 & 20.26 & 19.96 & 0 & 110.2 \\
leverage & 1191 & 1.220 & 4.947 & -118.1 & 60.30 \\
tfp lp & 1186 & 0.381 & 0.250 & 0.015 & 4.017 \\
Lproductiv_add & 1188 & 23.23 & 1.676 & 16.56 & 25.68 \\
roa & 1191 & 0.0311 & 0.0700 & -1.206 & 0.288 \\
\hline
\end{tabular}

\section{Research Design and Results Analysis}

\subsection{Research Design}

\subsubsection{Step 1-Single-Equation Probit Approach for Host-Country Agglomeration Effect}

To start with, a singer equation was used to investigate the impact of the agglomeration effect on the firms' OFDI location decisions.

Let $O F D I_{i k t}$ be a dummy variable that takes the value 1 if firm $i$ chooses to invest in host country $k$ in year $t$, and 0 otherwise. It was assumed that a firm would only undertake an OFDI project when the latent variable OFDI $I_{i k t}^{*}$ was positive. The latent variable depends on a vector of factors that includes the agglomeration effect in country $k$ in year $t$, which is denoted $H_{k t}$.

$$
O F D I_{i k t}=1 \text { if otherwise }
$$

here

$$
O F D I_{i k t}^{*}=\beta X_{-} \text {country } y_{k t}+\gamma H_{k t}+\varepsilon_{j k}
$$

and $H_{k t}$ is the agglomeration level in country $k, X_{-}$country $k_{t}$ is a vector for the OFDI $I_{i k t}^{*}$ determinants other than agglomeration, and $\beta$ (vector) and $\gamma$ are parameters. This equation was estimated as a Probit model. In the subsequent discussion and in the regression tables, the above equation was labelled "OFDI entry equation". This estimation approach was used to test Hypotheses 1-4.

The same estimation approach was used to test Hypothesis 5. For the samples that had conducted OFDI in the OBOR countries, let Obor $_{i k t}$ be a dummy variable that takes the value 1 if firm $i$ 's investment is located in OBOR countries in year $t$, and 0 otherwise. It was assumed that a firm would select the OBOR countries as the host country only when the latent variable Obor ${ }_{i k t}^{*}$ was positive. The latent variable depended on a vector of factors, which included the industry-country agglomeration effect in country $k$ in year $t$, denoted $H_{j k t}$.

$$
\text { Obor }_{i k t}=1 \text { if } \text { Obor }_{i k t}^{*}>0 \quad \text { Obor }_{i k t}=1 \text { if otherwise }
$$

where

$$
\text { Obor }_{i k t}^{*}=\beta X \_ \text {country } y_{k t}+\gamma H_{k t}+\varepsilon_{j k}
$$

and $H_{j k t}$ is the agglomeration level in country $k$ in year $t, X_{-}$firm $_{k t}$ is a vector of the firm characteristics that might affect the firm's location choice other than agglomeration in OBOR countries, denoted 
Obor $_{i k t}^{*}$, and $\beta$ (vector), and $\gamma$ are parameters. This equation was estimated as a Probit model to test whether the BRI encouraged new Chinese investors to locate in countries along the route.

\subsubsection{Step 2-FGLS Estimation Approach}

FGLS (feasible generalized least squares) estimation was used with a heteroscedastic error term to determine the firm characteristics when investing along the OBOR. As the dataset was an unbalanced panel with missing data, this model allowed for estimation in the presence of autocorrelation within panels, and cross-sectional correlation and heteroskedasticity across panels. A year dummy and a firm dummy were also added to increase the likelihood that there were no correlations across individuals.

To check the robustness of the FGLS regressions, the regression results were reported using a robust Ordinary Least Square estimation method.

The basic model for the FGLS is specified in a reduced form as

$$
Y_{i k t}=\beta X_{-} \text {firm }_{k t}^{\prime}+\varepsilon_{i k t}
$$

where $Y_{i k t}$ is the logarithm of Firm $i$ 's investment volume in country $k$ in year $t$ (firm $i$ belongs to industry $j), X_{-}$firm $^{\prime}{ }_{k t}$ denotes a vector for the firm characteristics such as roe, productivity, and size, etc., $\beta$ is a scalar, and $\varepsilon_{i k t}$ is a stochastic error term, which was assumed to be uncorrelated over all $i, k$, and $t$. Estimations were only run on firms that invested in OBOR countries to prove Hypothesis 6.

\subsection{Estimation Results Analysis}

\subsubsection{Agglomeration Effect Identification}

Table 3 shows the significant agglomeration effect at the country level, and indicates that there was a strong pattern for Chinese firms to invest in host countries where there was a large OFDI volume from Chinese sources in previous years (Irfdi_byChina had a positive sign); therefore, Hypothesis 1 was proved. As uncertainties about the host country are major obstacles to Chinese firms considering "going abroad", when there are previous Chinese firms, these can be a good learning object. As firms from the same country have the same language, cultural identity, ethnic connections, similar social networks, and similar environments, it is easier for companies from the same country to enter new markets with similar challenges. Former experience, no matter whether it is from their own or other Chinese firms can greatly improve the confidence and efficiency of the cross-border investment. Information asymmetry is also minimized when there are already Chinese firms operating in the host country. Further, the links between Chinese firms can strengthen the market power or even optimize the supply chain to guarantee the performance of the Chinese affiliates in the host country. This result was consistent with existing literature that indicated that Chinese firms preferred to invest in countries with higher Chinese OFDI concentrations [21,27]. 
Table 3. Firm Entry Model-Agglomeration Effect Identification ${ }^{1}$.

\begin{tabular}{|c|c|c|c|c|c|c|}
\hline \multirow[b]{3}{*}{ VARIABLES } & (1) & (2) & (3) & (4) & (5) & (6) \\
\hline & \multicolumn{3}{|c|}{ Country-Level Effect } & \multicolumn{3}{|c|}{ Industry-Level Effect } \\
\hline & $\begin{array}{c}\text { ofdi } \\
\text { (Full Sample) }\end{array}$ & obor & $\begin{array}{c}\text { ofdi } \\
\left(\text { Top } 15^{2}\right)\end{array}$ & $\begin{array}{c}\text { ofdi } \\
\text { (Full Sample) }\end{array}$ & obor & $\begin{array}{c}\text { ofdi } \\
\text { (Top 15) }\end{array}$ \\
\hline Agg_byindustry & & & & $\begin{array}{l}57.17^{* *} \\
(28.49)\end{array}$ & $\begin{array}{c}0.000551^{* * *} \\
(0.000166)\end{array}$ & $\begin{array}{l}1019 * \\
(555.2)\end{array}$ \\
\hline Industryshare_host & & & & $\begin{array}{c}0.00518 \\
(0.00965)\end{array}$ & $\begin{array}{l}0.0199 * * * \\
(0.00690)\end{array}$ & $\begin{array}{l}0.239 * * * \\
(0.0885)\end{array}$ \\
\hline Ifdifforeign & $\begin{array}{l}-0.0120 * * \\
(0.00484)\end{array}$ & $\begin{array}{l}0.0204^{*} \\
(0.0106)\end{array}$ & $\begin{array}{c}-0.0251 * * \\
(0.0128)\end{array}$ & & & \\
\hline Irfdi_bychina & $\begin{array}{c}0.0603^{* * *} \\
(0.0112)\end{array}$ & $\begin{array}{c}0.0623^{* * *} \\
(0.0167)\end{array}$ & $\begin{array}{l}-0.0219 \\
(0.0280)\end{array}$ & & & \\
\hline ltech & $\begin{array}{c}-0.0276^{* * *} \\
(0.00756)\end{array}$ & $\begin{array}{c}-0.0448^{* * *} \\
(0.00905)\end{array}$ & $\begin{array}{c}-0.0165 \\
(0.100)\end{array}$ & $\begin{array}{l}-0.0181 * \\
(0.00993)\end{array}$ & $\begin{array}{c}-0.0594^{* * *} \\
(0.0102)\end{array}$ & $\begin{array}{l}-0.218 \\
(0.175)\end{array}$ \\
\hline pe & $\begin{array}{c}0.114 \\
(0.0838)\end{array}$ & $\begin{array}{l}0.0317 \\
(0.115)\end{array}$ & $\begin{array}{l}0.0907 \\
(0.123)\end{array}$ & $\begin{array}{l}-0.121 \\
(0.127)\end{array}$ & $\begin{array}{l}-0.103 \\
(0.120)\end{array}$ & $\begin{array}{c}-0.428^{* *} \\
(0.215)\end{array}$ \\
\hline Imeanr & $\begin{array}{c}-0.122 * * * \\
(0.0201)\end{array}$ & $\begin{array}{c}-0.284^{* * *} \\
(0.0435)\end{array}$ & $\begin{array}{c}-1.962 * * * \\
(0.607)\end{array}$ & $\begin{array}{l}-0.0630 * \\
(0.0346)\end{array}$ & $\begin{array}{c}-0.301^{* * *} \\
(0.0445)\end{array}$ & $\begin{array}{l}-1.257 \\
(1.244)\end{array}$ \\
\hline lrw & $\begin{array}{c}-0.207^{* * *} \\
(0.0634)\end{array}$ & $\begin{array}{c}-0.449 * * * \\
(0.0934)\end{array}$ & $\begin{array}{c}-0.00826 \\
(0.0677)\end{array}$ & $\begin{array}{c}-0.0982 \\
(0.120)\end{array}$ & $\begin{array}{c}-0.423 * * * \\
(0.0986)\end{array}$ & $\begin{array}{c}-0.199 * \\
(0.107)\end{array}$ \\
\hline gdp_growth & $\begin{array}{c}-0.0327^{* * *} \\
(0.0108)\end{array}$ & $\begin{array}{c}-0.0381 * * * \\
(0.0147)\end{array}$ & $\begin{array}{c}1.801 * * * \\
(0.634)\end{array}$ & $\begin{array}{c}-0.0331 * \\
(0.0178)\end{array}$ & $\begin{array}{c}-0.0365 * * \\
(0.0151)\end{array}$ & $\begin{array}{c}0.714 \\
(1.178)\end{array}$ \\
\hline resource & $\begin{array}{l}0.0109^{* * *} \\
(0.00367)\end{array}$ & $\begin{array}{l}0.0164^{* * *} \\
(0.00512)\end{array}$ & $\begin{array}{c}0.0120 \\
(0.0194)\end{array}$ & $\begin{array}{c}0.0119 * \\
(0.00674)\end{array}$ & $\begin{array}{l}0.0227^{* * *} \\
(0.00717)\end{array}$ & $\begin{array}{l}-0.0691 \\
(0.0536)\end{array}$ \\
\hline infra & $\begin{array}{l}0.0223 * * * \\
(0.00405)\end{array}$ & $\begin{array}{c}0.00639 \\
(0.00508)\end{array}$ & $\begin{array}{c}0.0744^{* * *} \\
(0.0198)\end{array}$ & $\begin{array}{l}0.0255^{* * *} \\
(0.00728)\end{array}$ & $\begin{array}{c}0.00555 \\
(0.00611)\end{array}$ & $\begin{array}{c}0.0635^{* * *} \\
(0.0241)\end{array}$ \\
\hline plcy & & $\begin{array}{l}0.221^{*} \\
(0.126)\end{array}$ & & & $\begin{array}{c}0.263^{* *} \\
(0.119)\end{array}$ & \\
\hline Constant & $\begin{array}{l}-0.350 \\
(0.272)\end{array}$ & $\begin{array}{l}-0.560 \\
(0.388)\end{array}$ & $\begin{array}{c}-0.0348 \\
(3.469)\end{array}$ & $\begin{array}{c}-1.218^{* *} \\
(0.613)\end{array}$ & $\begin{array}{l}-0.685 \\
(0.546)\end{array}$ & $\begin{array}{l}-2.406 \\
(3.786)\end{array}$ \\
\hline Year Dummy & Yes & Yes & Yes & Yes & Yes & \\
\hline Observations & 1216 & 1216 & 146 & 1158 & 1158 & 123 \\
\hline Pseudo R-squared & 0.132 & 0.202 & 0.388 & 0.683 & 0.250 & 0.755 \\
\hline
\end{tabular}

Robust standard errors in parentheses, ${ }^{* * *} p<0.01,{ }^{* *} p<0.05,{ }^{*} p<0.1 .{ }^{1}$ Due to the length of paper, an extended version of table with the estimates of firm and year dummies is available by request. ${ }^{2}$ Top 15 is the top 15 countries that attracts most of the Chinese OFDI stock by 2016.

On the contrary, the lfdi_foreign had a negative coefficient, which indicated that Chinese firms were discouraged from investing in host countries when there was a larger previous non-Chinese OFDI volume. This result was not in line with Hypothesis 2, as most existing research has suggested that new foreign firms are more likely to locate near other foreign investors as the experience and performance of earlier investors is taken as an indicator of the business environment at the location (Boudier-Bensabaa [22] on Hungary, Meyer and Nguyen [23] on Vietnam, Head and Ries [18] and Cheng and Ruan [24] on China, Crozet et al. [19] on France, and Guimaraes et al. [13] on Portugal). While these results indicated a different pattern, this may have been because of a "location differentiation strategy". When entering a new market, Chinese firms often avoid direct competition with existing non-Chinese foreign investors, which are still the main engines of foreign direct investment. Compared with foreign investors from developed countries, Chinese investors are less competitive in many aspects such as technology, management, and investment experience. Therefore, a differentiated location strategy may be taken by Chinese firms when they choose to "go out". Another explanation could be related to the host country's investment policies. Host countries are more open to FDI that can bring capital, resources, or technologies; therefore, because Chinese OFDI is often seen resource-seeking, technology-seeking, and market-seeking, entry may be more difficult for Chinese firms seeking to enter host countries that have strict FDI policies and fierce competition. Host countries that are not major destinations for investors from developed economies might attract more Chinese OFDI. 
On the industry level, the results showed that only Agg_byindustry was significantly positive in the full sample Probit model (column 3, Table 3); therefore, Hypothesis 3 was proved. Chinese firms tend to choose horizontal rather than vertical investment [4] and prefer industries that they are familiar with or that have the same type of large investments from China. Knowledge spillovers enable investors to feel more secure about OFDI success as they can learn about the experiences from earlier home-country investors in corresponding industries already in the host country [25]. Another explanation is that Chinese firms that have invested in the industry and have FDI experience can reduce the costs of finding market information and the negative impacts of external disadvantage, thereby reducing investment uncertainty. Therefore, they can more easily adapt to the new external market by learning from their investment home country experience in the same industry.

We take out the top 15 countries which attract most of the Chinese OFDI in our sample countries (see Appendix A Table A1 for detail) and run probit estimations on both the country-level and industry-level agglomeration effects. The results (column 3 and 6) are in accordance with the full sample which shows our estimation is sound and robust.

With related to sectoral agglomeration effects. Table 4 shows the industry agglomeration index (Agg_byindustry) we use to quantify the agglomeration effects on different industries. Considering the average and median of the index, the industry with the most significant agglomeration is $C$ (manufacturing); B (Mining) and K (Real Estates) follow as the second and third most agglomerated industries. Owing to the small sample of outward investment events in other industries, there is no obvious agglomeration effect in the previous period of the corresponding year.

Table 4. Industry agglomeration index of Chinese OFDI (Agg_byindustry).

\begin{tabular}{cccc}
\hline Industry Code & Industry & Median & Mean \\
\hline A & Agriculture, Forestry, Animal Husbandry and Fishery & 2.4158 & 2.3729 \\
B & Mining & 3.5223 & 3.3237 \\
C & Manufacturing & 36.9492 & 34.9786 \\
D & Electrical Power, Heating, Natural Gas and Water & 2.0000 & 2.0498 \\
E & Construction & 2.1598 & 2.1066 \\
F & Wholesale and Retail & 2.3944 & 2.4642 \\
J & Finance & 2.1859 & 2.1859 \\
K & Real Estates & 2.9891 & 3.3531 \\
L & Rental and Commercial Services & 2.0000 & 2.0000 \\
R & Culture, Sports and Entertainment & 2.4968 & 2.4794 \\
S & Others & 1.9028 & 1.9028 \\
\hline
\end{tabular}

Note: 1. Mean and median is calculated as the average index of all sample years from 2004 to 2015. 2. Industry G (Transportation, Logistics and Postal Services), H (Food and Lodging), M (Science and Technology Services), N (Water Conservancy, Environmental, and Public Infrastructure), O (Residential Services, Repairs and Other Services), $\mathrm{P}$ (Education), and Q (Health and Social Work) are not subject to the agglomeration effect due to few investment events in the previous period of the corresponding year.

It was also found that some host country characteristics were core attributes for Chinese OFDI location choices. Chinese OFDI was more focused on countries with relatively low technology, wages, and economic growth (cost-seeking). Therefore, Chinese-listed firms OFDI activities were found to be more common in countries that had relatively high resource endowments (resource-seeking), infrastructure facilities, and host-country currency appreciation against the CNY. These results were in line with most previous research [2-4,51]. Additionally, in the OBOR regions, Chinese OFDI decisions are often characterized as market-seeking, resource-seeking, and cost-seeking, tending to be in countries or regions with high market potential, abundant natural resources, and low labor costs [34].

\subsubsection{Country Agglomeration Effect by Continents}

The location choice of the firm largely depends on geographical differences influenced by investment motives which might generate divergence in the result. Based on different investment 
motives, Chinese OFDI presents different distribution characteristics. This difference in geographical distribution is reflected not only between developed and developing countries [52,53], but also between continents. The degree of regional concentration of China's foreign investment is very high and the investment concentration diverges between continents [54]. This paper further investigates geographic distribution of OFDI and its effects by introducing interaction continent dummy variable (Four interaction continent dummy variable are constructed. Asia, Africa, Europe and America equal to 1 if countries fall within these continents, otherwise equals to 0 . Antarctica is omitted due to no observations in our sample. Table A7 describes the detailed country names in our sample.). Table 5 shows inconsistent results for country agglomeration effects. In Asia and Europe, firms tend to invest in countries that have less Chinese investment agglomeration; the result could be explained as a "competition avoidance" effect because these two continents are already the dominant destination for Chinese OFDI (16 out of top 20 Chinese OFDI destinations by stock in Appendix A Table A2 located in these two continents). In order to avoid competition, Chinese firms tend to choose countries with relatively less Chinese OFDI in previous year because seeking new market in these two continents would not be easy. This conclusion is consistent with some scholars' research which holds that the huge domestic market of developed countries has a reverse effect on Chinese direct investment so that Western Europe and Japan are not the first choice for China's market-seeking firms because of their fierce market competition and high entry level [53,55]. In Africa and America, the results show positive tendency for Chinese firms' investment decision related to previous Chinese investment agglomeration. New Chinese investors follow earlier peers because host countries in these continents are generally abundant with natural resources but have an unstable financial and/or political environment. Investment safety consideration makes firms to locate near each other. For other host country characteristics, it can be seen that Chinese firms are more resource-seeking in Africa and America (resource gets positive significance), technology-seeking and market seeking in Europe (ltech and gdp-growth have positive significance), cost-seeking (mainly labor cost) in Asia, Africa, and America (lrw has positive significance).

Table 5. Probit estimation results of country agglomeration effects using continent subsamples ${ }^{1}$.

\begin{tabular}{ccccc}
\hline & Asia & Africa & Europe & America \\
\hline VARIABLES & ofdi & ofdi & ofdi & ofdi \\
\hline \multirow{3}{*}{ lrfdi_bychina } & & & & \\
& $-0.0332^{* * *}$ & $0.118^{* * *}$ & $-0.0763^{*}$ & $0.113^{* *}$ \\
lfdi_foreign & $(0.0149)$ & $(0.0316)$ & $(0.0424)$ & $(0.0445)$ \\
& $0.524^{* * *}$ & $-0.0542^{*}$ & $-0.0271^{* * *}$ & $0.0484^{*}$ \\
ltech & $(0.0897)$ & $(0.0291)$ & $(0.00901)$ & $(0.0294)$ \\
& $-0.323^{* * *}$ & -0.0107 & $0.448^{* * *}$ & -0.0307 \\
lmeanr & $(0.0387)$ & $(0.0128)$ & $(0.107)$ & $(0.0248)$ \\
& -0.0196 & $-0.365^{* * *}$ & $-0.189^{* * *}$ & $-0.219^{* *}$ \\
lrw & $(0.0528)$ & $(0.0562)$ & $(0.0611)$ & $(0.103)$ \\
& $-0.778^{* * *}$ & $-0.606^{* * *}$ & 0.101 & $-1.698^{* * *}$ \\
gdp_growth & $(0.204)$ & $(0.170)$ & $(0.337)$ & $(0.607)$ \\
& $-0.136^{* * *}$ & 0.0195 & $0.147^{* * *}$ & $-0.244^{* * *}$ \\
pe & $(0.0284)$ & $(0.0298)$ & $(0.0615)$ & $(0.0721)$ \\
& $1.208^{* * *}$ & 0.165 & $0.477^{*}$ & 0.465 \\
resource & $(0.246)$ & $(0.224)$ & $(0.254)$ & $(0.382)$ \\
infra & -0.00425 & $0.0690^{* * *}$ & $-0.778^{* * * *}$ & $0.0497^{*}$ \\
& $(0.00740)$ & $(0.0115)$ & $(0.167)$ & $(0.0294)$ \\
Constant & $0.0469^{* * *}$ & $0.136^{* * *}$ & $-0.0409^{* * * *}$ & $0.0819^{* * *}$ \\
& $(0.0134)$ & $(0.0331)$ & $(0.0111)$ & $(0.0370)$ \\
Year Dummy & $-5.163^{* * *}$ & $-2.396^{* * *}$ & $-12.53^{* * * *}$ & 2.989 \\
Observations & $(1.390)$ & $(0.829)$ & $(3.343)$ & $(2.314)$ \\
Pseudo R-squared & Yes & Yes & Yes & Yes \\
Correctly Classified & 390 & 324 & 331 & 143 \\
& 0.486 & 0.450 & 0.466 & 0.389 \\
& 0.9154 & 0.9175 & 0.9204 & 0.8869 \\
\hline
\end{tabular}

Robust standard errors in parentheses, ${ }^{* * *} p<0.01,{ }^{* *} p<0.05,{ }^{*} p<0.1 .{ }^{1}$ Due to the length of paper, an extended version of table with the estimates of firm and year dummies is available by request. 


\subsubsection{BRI and Policy Effects on OFDI Agglomeration}

In models 2 and 4 of Table 3 indicate that there is a strong positive connection between Chinese OFDI and investment agglomeration on both a country and industry level in the OBOR countries (lrfdi_byChina, lrfdi_foreign, agg_byindustry, and industryshare_host were all significantly positive). Chinese firms followed earlier FDI investments from both China and non-Chinese investors in the OBOR countries. When host countries have a larger agglomeration of Chinese and other foreign investment in the same industry, Chinese firms are more willing to invest. In addition, the policy effect after the introduction of the BRI on listed firms' OFDI location decision-making was found to be significantly positive (Plcy was significantly positive in both models); therefore, Hypothesis 5 was proved.

An upgrade from the previous "Going out Strategy", which aimed to connect China more closely to Central Asia, Southeast Asia, South Asia, Russia, and the Baltics, the BRI has been effective because the Chinese government has been strongly promoting investment in the related countries. This is a problem most firms face when considering the financial risk of OFDI, especially when investing in OBOR countries with political uncertainties and financial restrictions. The Chinese government has been promoting investment in OBOR countries by offering financing options through policy-related banks, such as the Import and Export Bank of China, the AIIB (Asian Infrastructure Investment Bank), and other commercial banks, most of which have been involved in financing infrastructure along the BRI route. The Import and Export Bank of China reported that from 2013 to 2017, 1200 projects in more than 50 OBOR countries had been financed, with total loans exceeding 100 billion US dollars. It was also reported in the AIIB 2017 annual report that 23 projects worth 4.22 billion US dollars had been approved since the establishment of AIIB in 2016. With policy endorsement and stimulus as well as financing preferences, firms are more willing to locate their OFDI projects in OBOR countries even though these countries might have higher political or financial uncertainties [56].

\subsubsection{Firm Characteristics and Chinese OFDI Agglomeration Along "Belt and Road"}

Table 6 shows the linkages found between the financial statuses of the invested firms and the investment volume diverged from classical investment theories. Listed larger firms with higher leverage and lower productivity (Tfp_l $p$ ) and profitability were found to invest more along the "Belt and Road". State-owned firms were more actively investing in large projects in OBOR countries, which may be because it is easier for large state-owned firms to get financing from the policy-related banks; however, this does not mean that they are more productive or effective than private firms (Figure 3). It appears that the Chinese firms investing in response to the BRI were large firms with lower efficiency, which was not in line with the research that argued that firms should invest when they have high productivity and efficiency $[37,38,57,58]$. This finding also provides some proof for the recent observation that Chinese OFDI firms generally has poor financial performance [42-44]. Unfortunately, low efficient firms that conduct ODFI may be unable to generate synergies $[40,41]$. 
Table 6. Estimation results for firm characteristics and OFDI in One Belt One Road (OBOR) ${ }^{1}$.

\begin{tabular}{ccccc}
\hline & $\begin{array}{c}\text { OLS-Robust } \\
\text { OBOR }\end{array}$ & $\begin{array}{c}\text { OLS-Robust } \\
\text { OBOR }\end{array}$ & $\begin{array}{c}\text { FGLS } \\
\text { OBOR }\end{array}$ & $\begin{array}{c}\text { FGLS } \\
\text { OBOR }\end{array}$ \\
\hline VARIABLES & lcap & lcap & lcap & lcap \\
\hline state & -0.530 & -0.539 & $0.311^{* * *}$ & $0.323^{* * *}$ \\
ltoatlasset & $(0.463)$ & $(0.463)$ & $(0.112)$ & $(0.106)$ \\
& $1.229^{*}$ & 0.0753 & $1.503^{* * *}$ & $0.985^{* * *}$ \\
leverage & $(0.663)$ & $(0.506)$ & $(0.108)$ & $(0.0735)$ \\
& 0.00392 & 0.00381 & $0.00999^{*}$ & $0.00993^{*}$ \\
tfp_lp & $(0.00706)$ & $(0.00706)$ & $(0.00554)$ & $(0.00557)$ \\
& & $-1.150^{* *}$ & & $-0.536^{* * * *}$ \\
lproductivity_add & $-1.108^{*}$ & $(0.562)$ & & $(0.117)$ \\
& $(0.565)$ & & $-0.502^{* * *}$ & \\
roa & -3.646 & -3.487 & $-0.9244^{*}$ & $-0.926^{* *}$ \\
& $(2.941)$ & $(2.943)$ & & -28 \\
Constant & 10.16 & 10.31 & $-10.43^{* * *}$ & $(15,343)$ \\
& $(9.604)$ & $(9.567)$ & $(2.732)$ & Yes \\
Firm Dummy & Yes & Yes & Yes & Yes \\
Year Dummy & Yes & Yes & Yes & 403 \\
Observations & 496 & 496 & 405 & \\
R-squared & 0.399 & 0.399 & &
\end{tabular}

Standard errors in parentheses, ${ }^{* * *} p<0.01,{ }^{* *} p<0.05,{ }^{*} p<0.1 .{ }^{1}$ Due to the length of paper, an extended version of table with the estimates of firm and year dummies is available by request.

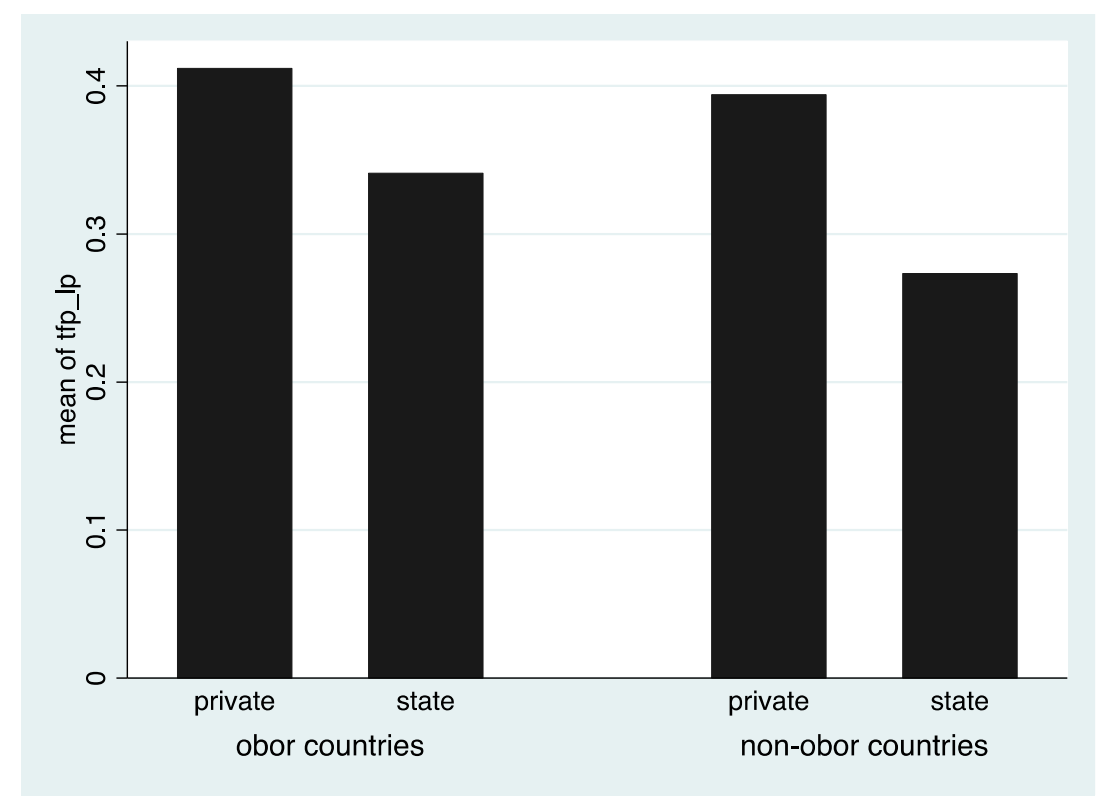

Figure 3. Comparison of Total Factor Productivity (State vs. Private).

\section{Conclusions and Implications}

This paper developed four agglomeration variables for Chinese OFDI at both the industry and country level, based on which, the following conclusions were made.

(1) There was an obvious agglomeration effect on host country selection for Chinese OFDI. Firms were found to follow other Chinese firms and invest in host countries where previous Chinese investment was concentrated, and were found to avoid countries that had large non-Chinese FDI in general. By breaking full sample countries to four continents, differences are revealed due to OFDI motivations and heterogeneity of continents. In Asia and Europe, firms tend to invest in countries that has less Chinese investment agglomeration. In Arica and America, the results show positive tendency for Chinese firms' investment decision related to previous Chinese investment agglomeration. 
(2) There was also an obvious agglomeration effect in terms of Chinese OFDI industry selection. Firms were found to prefer to invest in industries for which there was already a large Chinese OFDI agglomeration or high host-country related industry agglomeration.

(3) The BRI was found to be influential in encouraging OFDI location decisions, with many firms choosing to tend to invest along the "Belt and Road" route.

(4) Listed larger firms with higher leverage and lower productivity (Tfp_lp or lproductiviey_add) and profitability were more likely to invest along the "Belt and Road", with state-owned firms being more active investors in large projects in the OBOR countries.

From this analysis of Chinese OFDI, it was concluded that the agglomeration effect should be seen as an important index when evaluating host country location or industry selections. OFDI policies should be carefully designed to have a guiding effect on Chinese firm location choices. Medium-sized firms and private firms should be encouraged to be more responsive to OFDI as they are generally more productive, efficient, and adaptable to competition. To assist firms avoid any irrational follow-up behavior caused by information asymmetry, the relevant authorities need to establish effective information dissemination channels to further promote the smooth flow of investment information between firms and reduce the risk and investment cost in foreign countries, and especially in those with poor political and financial environments.

Author Contributions: Conceptualization and methodology, H.L. and J.J.; validation and formal analysis, H.L.; investigation, L.Z.; resources, X.C.; writing—original draft preparation, H.L.; writing—review and editing, H.L. and J.J.

Funding: This research was funded by National Natural Science Foundation of China: 61563044, 61762074, National Natural Science Foundation of Qinghai Province: 2017-ZJ-902, MOE (Ministry of Education in China) Project of Humanities and Social Sciences: 17YJC790094.

Conflicts of Interest: The authors declare no conflict of interest. The funders had no role in the design of the study; in the collection, analyses, or interpretation of data; in the writing of the manuscript, or in the decision to publish the results.

\section{Appendix A}

Table A1. The top 20 non-OBOR Countries (Regions) of Chinese OFDI Stock (By 2016). Unit: 100 million US dollars.

\begin{tabular}{cccc}
\hline Rank & Country & Stock & Weight (\%) \\
\hline 1 & United States & 605.8 & 4.4 \\
2 & Australia & 333.51 & 2.5 \\
3 & Canada & 127.26 & 0.9 \\
4 & South African & 60.01 & 0.4 \\
5 & Korea & 42.37 & 0.3 \\
6 & Congo & 35.15 & 0.3 \\
7 & Japan & 31.84 & 0.2 \\
8 & Brazil & 29.63 & 0.2 \\
9 & Venezuela & 27.42 & 0.2 \\
10 & Zambia & 26.87 & 0.2 \\
11 & Nigeria & 25.42 & 0.2 \\
12 & Bermuda & 21.66 & 0.2 \\
13 & New Zealand & 21.02 & 0.2 \\
14 & Ethiopia & 20.01 & 0.1 \\
15 & Ghana & 19.58 & 0.1 \\
16 & Argentina & 19.44 & 0.1 \\
17 & Papua New Guinea & 18.7 & 0.1 \\
18 & Zimbabwe & 18.39 & 0.1 \\
19 & Ecuador & 11.8 & 0.1 \\
20 & Mauritius & 11.76 & 0.1 \\
Total & & 1507.64 & 10.9 \\
\hline
\end{tabular}

Source: Ministry of Commerce, 2016 Statistical Bulletin of China's Outward Foreign Direct Investment. 
Table A2. The top 20 OBOR Countries (Regions) of Chinese OFDI Stock (By 2016). Unit: 100 million US dollars.

\begin{tabular}{cccc}
\hline Rank & Country & Stock & Weight (\%) \\
\hline 1 & Singapore & 334.46 & 2.5 \\
2 & The Netherlands & 205.88 & 1.5 \\
3 & United Kingdom & 176.12 & 1.3 \\
4 & Russian Federation & 129.8 & 1.0 \\
5 & Indonesia & 95.46 & 0.7 \\
6 & Luxembourg & 87.77 & 0.7 \\
7 & Germany & 78.42 & 0.6 \\
8 & Macao SAR, China & 67.83 & 0.5 \\
9 & Lao PDR & 55 & 0.4 \\
10 & Kazakhstan & 50.95 & 0.4 \\
11 & France & 51.16 & 0.4 \\
12 & Vietnam & 49.84 & 0.4 \\
13 & United Arab & 48.88 & 0.4 \\
14 & Emirates & 47.59 & 0.4 \\
15 & Pakistan & 46.2 & 0.3 \\
16 & Myanmar & 43.69 & 0.3 \\
17 & Cambodia & 42.3 & 0.3 \\
18 & Israel & 38.39 & 0.3 \\
19 & Mongolia & 36.34 & 0.3 \\
20 & Malaysia & 35.54 & 0.3 \\
Total & Sweden & 1721.62 & 12.9
\end{tabular}

Source: Ministry of Commerce,2016 Statistical Bulletin of China's Outward Foreign Direct Investment.

Table A3. The top 20 Countries (Regions) of Chinese OFDI Stock (By 2016). Unit: 100 million US dollars.

\begin{tabular}{cccc}
\hline Weight (\%) & Weight (\%) & Weight (\%) & Weight (\%) \\
\hline 1 & United States & 605.8 & 4.4 \\
2 & Singapore & 334.46 & 2.5 \\
3 & Australia & 333.51 & 2.5 \\
4 & The Netherlands & 205.88 & 1.5 \\
5 & United Kingdom & 176.12 & 1.3 \\
6 & Russian Federation & 129.8 & 1 \\
7 & Canada & 127.26 & 0.9 \\
8 & Indonesia & 95.46 & 0.7 \\
9 & Luxembourg & 87.77 & 0.6 \\
10 & Germany & 78.42 & 0.6 \\
11 & Macao SAR, China & 67.83 & 0.5 \\
12 & South African & 60.01 & 0.4 \\
13 & Lao PDR & 55 & 0.4 \\
14 & Kazakhstan & 50.95 & 0.4 \\
15 & France & 51.16 & 0.4 \\
16 & Vietnam & 49.84 & 0.4 \\
17 & United Arab Emirates & 48.88 & 0.3 \\
18 & Pakistan & 47.59 & 0.4 \\
19 & Myanmar & 46.2 & 0.3 \\
20 & Cambodia & 43.69 & 0.3 \\
Total & & 2695.63 & 19.8 \\
\hline
\end{tabular}

Source: Ministry of Commerce, 2016 Statistical Bulletin of China's Outward Foreign Direct Investment. 


\section{Appendix B}

Table A4. Variables incorporated into the PE (political environment).

\begin{tabular}{cc}
\hline Grade 1 Index & Grade 2 Index \\
\hline Voice and Accountability & Military in politics \\
& Democratic accountability \\
\hline \multirow{2}{*}{ Globalization } & Social globalization \\
& Political globalization \\
& Overall globalization \\
\hline \multirow{2}{*}{ Freedom } & Business freedom \\
& Fiscal freedom \\
& Labor freedom \\
& Monetary freedom \\
& Investment freedom \\
Control of Corruption & Financial freedom \\
\hline \multirow{2}{*}{ Law and rights } & Corruption perceptions of transparent \\
& Freedom from corruption \\
\hline & Rule of law \\
& Property rights \\
& Political rights \\
\hline
\end{tabular}

\section{Appendix C}

Table A5. List of country names in entire sample.

\begin{tabular}{|c|c|c|c|c|}
\hline Afghanistan & Colombia & Iceland & Malawi & Sierra Leone \\
\hline Angola & Cuba & Israel & Malaysia & Suriname \\
\hline $\begin{array}{l}\text { United Arab } \\
\text { Emirates }\end{array}$ & Czech Republic & Italy & Namibia & Sweden \\
\hline Argentina & Germany & Jamaica & Niger & Syrian Arab Republic \\
\hline Australia & Denmark & Jordan & Nigeria & Chad \\
\hline Austria & Algeria & Japan & The Netherlands & Togo \\
\hline Azerbaijan & Ecuador & Kazakhstan & Norway & Thailand \\
\hline Burundi & Egypt, Arab Rep. & Kenya & New Zealand & Turkmenistan \\
\hline Belgium & Spain & Cambodia & Oman & Tunisia \\
\hline Benin & Ethiopia & Korea, Rep. & Pakistan & Turkey \\
\hline Bangladesh & Finland & Lao PDR & Panama & Tanzania \\
\hline Bulgaria & Fiji & Liberia & Peru & Uganda \\
\hline Iran, Islamic Rep. & France & Libya & Philippines & Ukraine \\
\hline Belarus & Gabon & Sri Lanka & $\begin{array}{c}\text { Papua New } \\
\text { Guinea }\end{array}$ & Uruguay \\
\hline Bermuda & United Kingdom & Lesotho & Poland & United States \\
\hline Bolivia & Georgia & Luxembourg & $\begin{array}{l}\text { Korea, Dem. } \\
\text { People's Rep. }\end{array}$ & Uzbekistan \\
\hline Brazil & Ghana & $\begin{array}{c}\text { Macao SAR, } \\
\text { China }\end{array}$ & Korea, Dem. Rep. & $\begin{array}{l}\text { St. Vincent and the } \\
\text { Grenadines }\end{array}$ \\
\hline Barbados & Guinea & Morocco & Portugal & Venezuela, RB \\
\hline Brunei Darussalam & Equatorial & Madagascar & Paraguay & Guinea \\
\hline
\end{tabular}


Table A5. Cont.

\begin{tabular}{ccccc}
\hline Botswana & Greece & Senegal & Qatar & Vietnam \\
\hline Canada & Congo, Rep. & Mauritania & Romania & Samoa \\
\hline Switzerland & Hungary & Mali & $\begin{array}{c}\text { Russian } \\
\text { Federation }\end{array}$ & Yemen, Rep. \\
\hline Chile & Indonesia & Myanmar & Rwanda & South Africa \\
\hline Cote d'Ivoire & India & Mongolia & Saudi Arabia & Zambia \\
\hline Cameroon & Ireland & Mozambique & Sudan & Zimbabwe \\
\hline Congo, Dem. Rep. & Iraq & Mauritius & Singapore & \\
\hline
\end{tabular}

Table A6. List of OBOR country names.

\begin{tabular}{ccccc}
\hline Afghanistan & Denmark & Ireland & Luxembourg & Romania \\
\hline $\begin{array}{c}\text { Angola } \\
\text { Emited Arab }\end{array}$ & Algeria & Iran, Islamic Rep. & Macao SAR, China & Russian Federation \\
\hline Austria & Spypt, Arab Rep. & Iraq & Myanmar & Saudi Arabia \\
\hline Azerbaijan & Finland & Iceland & Mongolia & Singapore \\
\hline Belgium & France & Israel & Malaysia & Sweden \\
\hline Bangladesh & United Kingdom & Italy & The Netherlands & $\begin{array}{c}\text { Syrian Arab } \\
\text { Republic }\end{array}$ \\
\hline Bulgaria & Georgia & Kazakhstan & Norway & Thailand \\
\hline Belarus & Greece & Cambodia & Pakistan & Turkmenistan \\
\hline Brunei Darussalam & Yemen, Rep. & Lao PDR & Philippines & Turkey \\
\hline Switzerland & Hungary & Liberia & Poland & Uzbekistan \\
\hline Czech Republic & Indonesia & Libya & Portugal & Vietnam \\
\hline Germany & India & Sri Lanka & Qatar & \\
\hline
\end{tabular}

Table A7. List of country names used for Asia, Europe, America, and Africa.

\begin{tabular}{ccccc}
\hline & \multicolumn{4}{c}{ Asia } \\
India & $\begin{array}{c}\text { Syrian Arab } \\
\text { Republic }\end{array}$ & $\begin{array}{c}\text { United Arab } \\
\text { Emirates }\end{array}$ & Sri Lanka & Georgia \\
\hline Oman & Lao PDR & Turkey & Philippines & Iran, Islamic Rep. \\
\hline Mongolia & Azerbaijan & Jordan & Malaysia & Kazakhstan \\
\hline Vietnam & Iraq & $\begin{array}{c}\text { Hong Kong SAR, } \\
\text { China }\end{array}$ & Israel & Korea, Rep. \\
\hline Yemen, Rep. & Saudi Arabia & Thailand & Qatar & Myanmar \\
\hline Cambodia & Turkmenistan & Uzbekistan & Macao SAR, China & Japan \\
\hline Singapore & Indonesia & Brunei Darussalam & Russian Federation & Korea, Dem. Rep. \\
\hline Afghanistan & Bangladesh & Pakistan & & \\
\hline Singapore & Indonesia & Brunei Darussalam & Russian Federation & Korea, Dem. Rep. \\
\hline Afghanistan & Bangladesh & Pakistan & & \\
\hline
\end{tabular}


Table A7. Cont.

\begin{tabular}{|c|c|c|c|c|}
\hline \multicolumn{5}{|c|}{ Europe } \\
\hline The Netherlands & Czech Republic & Hungary & Poland & Belgium \\
\hline Denmark & Spain & Romania & Sweden & Portugal \\
\hline Finland & Iceland & Ukraine & Austria & Belarus \\
\hline Germany & Norway & United Kingdom & Italy & France \\
\hline Luxembourg & Ireland & Bulgaria & $\begin{array}{c}\text { Russian } \\
\text { Federation }\end{array}$ & Greece \\
\hline \multicolumn{5}{|l|}{ Switzerland } \\
\hline \multicolumn{5}{|c|}{ America } \\
\hline Bermuda & Cuba & Suriname & $\begin{array}{l}\text { St. Vincent and } \\
\text { the Grenadines }\end{array}$ & Argentina \\
\hline Canada & Paraguay & Uruguay & United States & Chile \\
\hline Barbados & Ecuador & Colombia & Brazil & Mexico \\
\hline Jamaica & Venezuela, RB & Panama & Bolivia & Peru \\
\hline \multicolumn{5}{|c|}{ Africa } \\
\hline Congo, Rep. & Mauritius & Zambia & Uganda & Equatorial Guinea \\
\hline Botswana & Burundi & South Africa & Niger & Morocco \\
\hline Togo & Ethiopia & Liberia & Senegal & Cameroon \\
\hline Tunisia & Congo, Dem. Rep. & Mauritania & Madagascar & Angola \\
\hline Gabon & Sudan & Mozambique & Malawi & Chad \\
\hline Zimbabwe & Guinea & Cote d'Ivoire & Kenya & Egypt, Arab Rep. \\
\hline Benin & Sierra Leone & Nigeria & Mali & Tanzania \\
\hline Lesotho & Rwanda & Ghana & Libya & Namibia \\
\hline Algeria & & & & \\
\hline
\end{tabular}

\section{References}

1. Qi, J.; Liu, H. Does past experience affect the location choice of sequential investment in OFDI enterprises? Evidence from Chinese industrial enterprises. Econ. Theory Manag. 2015, 35, 100-112.

2. Buckley, P.J.; Clegg, L.J.; Cross, A.R.; Liu, X.; Voss, H.; Zheng, P. The determinants of Chinese outward foreign direct investment. J. Int. Bus. Stud. 2007, 38, 499-518. [CrossRef]

3. Kolstad, I.; Wiig, A. What determines Chinese outward FDI? J. World Bus. 2012, 47, 26-34. [CrossRef]

4. Liu, H.Y.; Deseatnicov, I. Exchange rate and Chinese outward FDI. Appl. Econ. 2016, 48, 4961-4976. [CrossRef]

5. Xie, J.; Liu, R. Study on the Influencing Factors and Trade Effects of China's Outward Direct Investment Based on Spatial Perspective. Int. Trade Issues 2011, 6, 66-74.

6. Head, K.; Ries, J.C.; Swenson, D. Agglomeration benefits and location choice: Evidence from Japanese manufacturing investments in the United States. J. Int. Econ. 1994, 38, 223-248. [CrossRef]

7. Fraley, R.C.; Shaver, P.R. Adult romantic attachment: Theoretical developments, emerging controversies, and unanswered questions. Rev. Gen. Psychol. 2000, 4, 132-154. [CrossRef]

8. Marshall, A. Principles of Economics: An Introductory Volume. Soc. Sci. Electron. Publ. 1920, 67, 457.

9. Krugman, P. Increasing returns and economic geography. J. Political Econ. 1991, 99, 483-499. [CrossRef]

10. Saxenian, A. High-Tech Dynamics. (Book Reviews: Regional Advantage. Culture and Competition in Silicon Valley and Route 128.). Science 1994, 264, 1614-1615.

11. Head, K.; Ries, J. International mergers and welfare under decentralized competition policy. Can. J. Econ. 1997, 30, 1104-1123. [CrossRef]

12. Barrell, R.; Pain, N. Trade restraints and Japanese direct investment flows. Eur. Econ. Rev. 1999, 43, $29-45$. [CrossRef] 
13. Guimaraes, P.; Figueiredo, O.; Woodward, D. Agglomeration and the location of foreign direct investment in Portugal. J. Urban Econ. 2000, 47, 115-135. [CrossRef]

14. Wheeler, D.; Mody, A. International investment location decisions: The case of U.S. firms. J. Int. Econ. 1992, 33, 57-76. [CrossRef]

15. Henisz, W.J.; Delios, A. Uncertainty, imitation, and plant location: Japanese multinational corporations, 1990-1996. Adm. Sci. Q. 2001, 46, 443-475. [CrossRef]

16. Gross, D.M.; Raff, H.; Ryan, M.J. Intra- and Inter-industry Linkages in Foreign Direct Investment: Evidence from Japanese Investment in Europe by. J. Jpn. Int. Econ. 2001, 19, 110-134. [CrossRef]

17. Head, K.; Ries, J. Inter-city competition for foreign investment: Static and dynamic effects of China's incentive areas. J. Urban Econ. 1996, 40, 38-60. [CrossRef]

18. Head, C.K.; Ries, J.C.; Swenson, D.L. Attracting foreign manufacturing: Investment promotion and agglomeration. Reg. Sci. Urban Econ. 1999, 29, 197-218. [CrossRef]

19. Crozet, M.; Mayer, T.; Mucchielli, J.L. How do firms agglomerate? A study of FDI in France. Reg. Sci. Urban Econ. 2004, 34, 27-54. [CrossRef]

20. Coughlin, C.; Segev, E. Locational determinants of new foreign manufacturing plants. J. Reg. Econ. 2000, 40, 323-351.

21. Qi, J.; Liu, H. Does the sequential investment of heterogeneous OFDI enterprises have "path dependence" of location selection? Int. Trade Issues 2015, 8, 123-134.

22. Boudier-Bensebaa, F. Agglomeration economies and location choice: Foreign direct investment in Hungary. Econ. Trans. 2010, 13, 605-628. [CrossRef]

23. Nguyen, T.V.; Weinstein, M.; Meyer, A.D. Development of trust: A study of interfirm relationships in Vietnam. Asia Pac. J. Manag. 2005, 22, 211-235. [CrossRef]

24. Cheng, H.; Ruan, X. Location Choice of China's Foreign Direct Investment by Gravity Model Analysis. World Econ. 2004, 11, 23-30.

25. Wang, J.; Jiang, J. Host-country agglomeration, industry cluster and Chinese OFDI in the USA. World Geogr. Res. 2017, 26, 20-30.

26. Gimeno, J.; Hoskisson, R.E.; Beal, B.D.; Wan, W.P. Explaining the clustering of international expansion moves: A critical test in the U.S. telecommunications industry. Acad. Manag. J. 2005, 48, 297-319. [CrossRef]

27. Lin, Y. Tidality Phenomenon and Reconstruction of Macroeconomic Theory in Developing Countries. Econ. Res. 2007, 1, 126-131.

28. Anand, J.; Delios, A. Absolute and relative resources as determinants of international acquisitions. Strateg. Manag. J. 2002, 23, 119-134. [CrossRef]

29. Meyer, K.E.; Wright, M.; Pruthi, S. Managing knowledge in foreign entry strategies: A resource-based analysis. Strat. Manag. J. 2009, 30, 557-574. [CrossRef]

30. Li, P.F. Horizontal versus vertical learning: Divergence and diversification of lead firms in the Hangji toothbrush cluster, China. Reg. Stud. 2014, 48, 1227-1241. [CrossRef]

31. Malmberg, A.; Maskell, P. Localized learning revisited. Growth Chang. 2010, 37, 1-18. [CrossRef]

32. Du, J.; Lu, Y.; Tao, Z. FDI location choice: Agglomeration vs. institutions. Int. J. Financ. Econ. 2008, 13, 92-107. [CrossRef]

33. Porter, M.E. Clusters and the new economics of competition. Harv. Bus. Rev. 1998, 76, 77-90. [PubMed]

34. Xiong, B. A study on the influence factors of China's direct investment in the countries along the route from the spatial perspective. J. Int. Trade 2018, 6, 102-112.

35. Zhang, S. Measures to promote China's foreign investment layout optimization under the "one belt and one road" initiative. Ref. Econ. Res. 2017, 30, 43-45.

36. Zhou, G.; Zhou, J.; Ji, K. The industry selection of China's foreign investment under the "belt and road initiative". Enterp. Econ. 2017, 9, 72-79.

37. Melitz, M.J. The Impact of Trade on Intra-Industry Reallocations and Aggregate Industry Productivity. Econometrica 2003, 71, 1695-1725. [CrossRef]

38. Helpman, E.; Melitz, M.J.; Yeaple, S.R. Export versus FDI with Heterogeneous Firms. Am. Econ. Rev. 2004, 94, 300-316. [CrossRef]

39. Branstetter, L. Is foreign direct investment a channel of knowledge spillovers? Evidence from Japan's FDI in the United States. J. Int. Econ. 2000, 68, 325-344. [CrossRef] 
40. Fu, L.; Gong, H.; Qi, W. Enterprise Heterogeneity and Foreign Direct Investment. Sci. Technol. Econ. 2016, $29,54-58$.

41. Tang, X.; Zhang, J. Corporate heterogeneity and foreign direct investment decision-making based on analysis of China's top 100 manufacturing companies. Jiangxi Soc. Sci. 2013, 1, 61-65.

42. Yi, L. An Analysis of the Current Situation and Problems of China's Outward Foreign Direct Investment. Market Mod. 2010, 22, 56.

43. Li, D. Analysis of the Status Quo and Existing Problems of China's Outward Direct Investment. Market Mod. 2016, 18, 212-213.

44. Yang, Y.; Liu, C. The relationship between foreign direct investment and China's industrial upgrading under the background of "one belt and one road". J. South China Norm. Univ. (Soc. Sci. Ed.) 2015, 5, 93-101.

45. Li, G. Path selection of China's foreign investment promotion international competitiveness under the "one belt and one way" initiative. Learn. Sea. 2016, 5, 137-143.

46. Liu, S. Analysis of the problem of going out of state-owned enterprises under the background of "one belt and one road". Fortune Today 2017, 5, 45-46.

47. Richardson, S. Over-investment of free cash flow. Rev. Account. Stud. 2006, 11, 159-189. [CrossRef]

48. Knyazeva, A.; Knyazeva, D.; Morck, R.; Yeung, B. Comovement in Investment. Soc. Sci. Electron. Publ. 2007. [CrossRef]

49. Kamal, M.A.; Li, Z.; Akhmat, G.; Bashir, M.F.; Khan, K. What determines China's FDI inflow to South Asia? Mediterr. J. Soc. Sci. 2014. [CrossRef]

50. Kiyota, K.; Urata, S. Exchange rate, exchange rate volatility and foreign direct investment. World Econ. 2010, 27, 1501-1536. [CrossRef]

51. Blonigen, B.A. A review of the empirical literature on FDI determinants. Atlantic Econ. J. 2005, 33, $383-403$. [CrossRef]

52. Liu, J.; Yao, C. China's FDI Industry Selection and Location Selection Analysis. J. Liaoning Norm. Univ. (Soc. Sci. Ed.) 2012, 35, 614-618.

53. Hu, B.; Ling, L. Location Selection of China's Foreign Direct Investment: From the Perspective of Investment Motivation. Int. Trade Issues 2008, 12, 96-102.

54. Zou, T.; Liu, H. Research on the Centralization of China's Foreign Investment Location Selection. Technol. Innov. Manag. 2010, 31, 65-68.

55. Li, M.; Yu, J. Correlation between Location Advantage of Host Country and Chinese Foreign Direct Investment (FDI). Based on the generalized moment estimation analysis of dynamic panel data. World Econ. Res. 2011, 6, 63-67.

56. Zu, W.; Liu, H. Exchange Rate Movements, Political Environment and Chinese Outward FDI in Countries Along “One Belt One Road". In Proceedings of the International Conference on Management Science and Engineering Management, Kanazawa, Japan, 28-31 July 2017; pp. 1439-1456.

57. Aitken, B.; Hanson, G.H.; Harrison, A.E. Spillovers, foreign investment, and export behavior. J. Int. Econ. 1997, 43, 103-132. [CrossRef]

58. Herzer, D. The Long-run Relationship between Outward Foreign Direct Investment and Total Factor Productivity: Evidence for Developing Countries. J. Dev. Stud. 2011, 47, 767-785. [CrossRef]

(C) 2018 by the authors. Licensee MDPI, Basel, Switzerland. This article is an open access article distributed under the terms and conditions of the Creative Commons Attribution (CC BY) license (http://creativecommons.org/licenses/by/4.0/). 